\title{
HUBUNGAN KARAKTERISTIK DENGAN PERILAKU PETERNAK TERHADAP KEGIATAN PENYULUHAN PEMBUATAN NUGGET SUSU DI DESA ORO-ORO OMBO KECAMATAN BATU
}

\author{
THE CORRELATION BETWEEN FARMER'S \\ CHARACTERISTICS WITH BEHAVIOR IN MILK-NUGGET \\ MAKING EXTENSION ACTIVITIES IN \\ ORO-ORO VILLAGE OMBO BATU DISTRICT
}

\author{
Fitriani $^{1}$, Luki Amar Hendrawati ${ }^{2}$, Andi Warnaen ${ }^{3}$ \\ ${ }^{1}$ Mahasiswa Politeknik Pembangunan Pertanian Malang \\ 2,3 Dosen Politeknik Pembangunan Pertanian Malang \\ Email: anifitri70@gmail.com
}

\begin{abstract}
ABSTRAK
Penelitian ini bertujuan untuk mengetahui hubungan umur, pendidikan dan jumlah ternak dengan perilaku peternak dalam kegiatan penyuluhan pembuatan nugget susu di Desa Oro-oro Ombo. Metode penentuan Desa menggunakan purposive sampling dengan pertimbangan desa tersebut memiliki jumlah peternak sapip perah lebih dari 1000 ekor. Sebanyak 34 responden dilibatkan dalam penelitian ini. Data dianalisis menggunakan deskriptif kuantitatif dan kualitatif. Hubungan umur, pendidikan dan jumlah ternak dengan perilaku diananlisis dengan analisis korelasi berganda dan korelasi product moment. Hasil penelitian menunjukkan bahwa pada indikator pengetahuan $(77,2 \%)$ responden berada pada tahap sintesa, indikator sikap (76\%) responden berada pada tahap mengelola, sedangkan indikator keterampilan $(75,7 \%)$ responden berada pada tahap artikulasi. Hasil analisis menunjukkan bahwa terdapat hubungan signifikan antara karakteristik responden dengan prilaku peternak sedangkan apabila dianalisis secara parsial hanya pendidikan (X1) dan jumlah ternak (X2) berhubungan secara signifikan dengan perilaku peternak.
\end{abstract}

Kata Kunci : Perilaku, Peternak sapi perah, penyuluhan

\begin{abstract}
ABSTRACK
This study aims to determine the relationship of age, education and the number of livestock with the behavior of pternak in extension activities of making milk nugget in Oro-oro Ombo Village. The method of determining the village using purposive sampling with the consideration of the village has a number of dairy farmers more than 1000 dairy cattle. A total of 34 respondents were included in this research. Data were analyzed using quantitative and qualitative descriptive. Age relationship, education and number of livestock with behavior with analysis of multiple correlation and product moment correlation. The result of the research shows that in the knowledge indicator (77.2\%) respondents are in the synthesis stage, the attitude indicator ( $76 \%$ ) of respondents is in managing stage, while the skill indicator $(75.7 \%)$ is in the articulation stage. The result of analysis shows that there is a significant correlation
\end{abstract}


between respondent characteristic and breeder behavior, while when analyzed partially only education (X1) and number of livestock (X2) correlated significantly with farmer behavior.

Keywords : Behavior, Dairy farmers, counseling

\section{PENDAHULUAN}

Susu segar merupakan bahan makanan yang sangat istimewa dan bergizi tinggi bagi manusia hal ini dikarenakan susu mengandung zat-zat makanan yang lengkap dan seimbang seperti protein, lemak, karbohidrat, mineral dan vitamin yang sangat dibutuhkan oleh manusia, namun dengan tingginya nilai gizi tersebut susu menjadi media yang sangat cocok bagi pertumbuhan dan perkembangan mikroorganisme sehingga dalam waktu singkat susu yang tidak ditangani dengan benar akan mudah rusak dan tidak layak konsumsi. Istilah susu kualtas rendah sudah tidak asing bagi peternak. Untuk menggulangi hal tersebut maka dibutuhkannya suatu teknologi pengolahan susu kualitas rendah. Salah satu upaya penganekaragaman pengolahan susu kualitas rendah adalah dengan mengolah susu menjadi nugget susu.

Desa Oro-oro Ombo merupakan salah satu sentra produksi penghasil susu di Kecamatan Batu. Dengan adanya teknologi pengolahan susu tersebut akan memacu pengembangan pengolahan susu skala rumah tangga maupun industri kecil di daerah sentra produksi susu melalui teknologi sederhana sesuai dengan ketersediaan sarana, prasarana dan kemampuan sumber daya manusia (SDM) yang terbatas. Penerapan teknologi ini diharapkan dapat memberikan nilai tambah secara ekonomi.

Menurut Salmet dalam Mardikanto (2009), inti dari kegiatan penyuluhan adalah untuk memberdayakan masyarakat. memberdayakan berarti memebri daya kepada yang tidak berdaya dan atau mengembangkan daya kepada yang sudah memiliki sesuatu yang lebih bermafaat bagi masyarakat yang bersangkutan. Dengan adanya penyuluhan pembuatan nugget susu ini diharapkan memiliki tindak lanjut yang dapat memebrdayakan masyarakat sekitar.

Perilaku merupakan segala tindakan yang dilakukan seseorang yang secara umum dipengaruhi oleh tiga hal yaitu pengetahuan, sikap, keterampilan. Terdapat tiga aspek dalam perilaku yaitu pengetahuan, sikap dan keterampilan. Pengetahuan merupakan segala sesuatu yang mencakup perubahan dari apa yang telah diketahui kurang menguntungkan menjadi lebih baik dan menguntungkan. Menurut Wibowo (2006) Sikap adalah kecenderungan atau kesediaan seseorang untuk bertingkah laku tertentu seandainya seseorang tersebut menghadapi suatu rangsang tertentu, sedangkan keterampilan menurut levis dalam mulyawati (2016) yang baik dalam beternak berarti petani ternak mampu merubah dirinya melalui komunikasi dengan orang lain untuk menentukan bagaimana kegiatan usaha akan menguntungkan. Perilaku beternak seorang peternak selain dilihat dari tiga aspek tersebut juga dipengaruhi oleh umur, pendidikan, pengalaman, dan jumlah ternak (Mulyawati, 2016).

Penelitian ini bertujuan untuk mengetahui hubungan karaktersitik responden: umur, pendidikan, jumlah ternak, jumlah ternak dengan perilaku dalam kegiatan penyuluhan pembuatan nugget susu di Desa Wonosari. Manfaat dari penelitian ini adalah dapat mengetahui bagaimana perilaku anggota Kelompok Wanita Tani di Desa Oro-oro Ombo.

\section{MATERI DAN METODE}

Penelitian dilaksanakan di Desa Oro-oro Ombo Kecamatan Singosari Kota Batu. Metode yang digunakan untuk menentukan lokasi menggunkan purposive sampling. Jumlah responden sebanyak 34 orang anggota KWT Pandermania yang 
dipilih dengan teknik sampel jenuh. Menurut Sugiyono (2016) Sampel jenuh merupakan teknik penentuan sampel bila semua anggota populasi dijadikan sebagai sampel. Metode pengumpulan data yang digunakan dengan mengumpulkan data primer dan data sekunder. Data sekunder berasal dari buku-buku yang berhubungan dengan penelitian dan keadaan penduduk sedangkan untuk data primer berasal dari kuisioner yang dibagikan kepada anggota kelompok wanita tani Pandermania Desa Oro-oro Ombo. Kuisioner atau angket merupakan teknik pengumpulan data yang dilakukan dengan cara memberi seperangkat pertanyaan atau pernyataan tertulis kepada responden untuk dijawab.

Analisis data dilakukan secara deskriptif. Hasil jawaban dari responden diolah dalam bentuk skor. Untuk menegtahui hubungan antara karakteristik responden dengan prilaku peternak menggunakan analisis yaitu analisis korelasi secara simultan menggunkan korelasi berganda dan analisis korelasi secara parsial menggunkan korelasi product moment.

\section{HASIL DAN PEMBAHASAN}

\section{Keadaan umum responden}

Hasil penelitian menunjukkan dari 34 responden dapat diketahui bahwa sebagian besra respondn masih berusia produktif yaitu $82 \%$ atau 28 dari 34 responden berumur 39-49 tahun berdasarkan persentase usia tersebut menunjukkan bahwa responden masih tergolong usia produktif dengan keadaan tersebut menunjukan keadaan kondisi fisik untuk bekerja secara optimal sehingga masih memiliki rasa ingin tahu yang tinggi terhadap sesuatu.

Murwanto (2008:3) tingkatan pendidikan merupakan indikator kualitas penduduk dan merupakan peubah kunci dalam pengembangan sumberdaya manusia hasil penelitian menunjukan $42 \%$ tingkat pendidikan petani responden adalah SLTP dengan jumlah 14 orang dari 34 responden.
Kepemilikan ternak responden sebanyak 13 orang (38\%) Rendahnya jumlah kepemilikan ternak akan mengakibatkan peternak berusaha meningkatkan produktivitas dan pendapatan dari ternak tersebut, dengan adanya hal tersebut diharapkan responden dapat lebih bersemangat dalam menerima informasi baru guna untuk meningkatkan pendapatan usahanya (Wibowo dan Haryadi, 2006).

\section{Rancangan Penyuluhan}

Penetapan rancangan penyuluhan melalui identifikasi wilayah, karakteristik sasaran dan kebutuhan sasaran dan dilakukan analisis menggunakan matriks fishbone dengan berdasarkan tingkat adopsi inovasi sasaran terhadap materi yang akan disuluhkan. Hasil identifikasi karakterstik sasaran dan kedaaan daerah dapat disimpulkan bahwa tingkat adopsi sasaran terhadap inovasi penganekaragaman produk susu kualitas rendah berada pada tahap menilai. Menurut Warnaen, dkk (2016:69) pada tahap menilai ini inovasi akan diuji dan dipertanyakan dari segi keuntungan inovasi, apakah cocok digunakan, tingkat kerumitannya apakah bisa dicoba dan diamati. Berdasarkan analisis tersebut maka dapat rancangan penyuluhan yang digunakan yaitu :

\section{Sasaran}

Sasaran penyuluhan yaitu wanita tani dari anggota Kelompok Wanita Tani Pandermania sejumlah 34 orang, mempunyai ternak sapi perah yang merupakan ternak milik sendiri sedangkan untuk pendidikan formal wanita tani di Desa Oro-oro Ombo sebagian besar adalah SLTP artinya responden dapat membaca dan menulis sehingga komunikasi dengan sasaran lebih mudah.

\section{Materi}

Materi penyuluhan yang diberikan adalah pembuatan nugget susu dengan penggunaan ekstrak nanas sebagai bahan penggumpal susu diangkat menjadi materi 
karena pengolahan tersebut merupakan suatu inovasi penganekaragaman susu kualitas rendah dan peternak membutuhkannya.

\section{Metode}

Peran metode sangat penting dalam proses komunikasi penyuluhan dan menetukan keberhasilan dari proses penyuluhan itu sendiri (Warnaen ,dkk., 2017:18). Metode penyuluhan pertanian pada lampiran 3 metode penyuluhan yang digunakan adalah diskusi kelompok dan demonstrasi cara.

\section{Media}

Menurut Romadi dan Hamyana (2009) suatu media harus tepat untuk mendukung isi materi penyuluhan yang sifatnya fakta, konsep, prinsip yang general agar dapat membantu proses pengajaran secara efektif.digunakan adalah media cetak berupa folder dan media audio visual berupa video tutorial pembuatan nugget susu.

\section{Perilaku Peternak}

Hasil penelitian tentang perilaku peternak dapat dilihat pada tabel 1 berikut ini:

Tabel 1. Perilaku peternak berdasarkan ranah taksonomi bloom

\begin{tabular}{lcc}
\hline \multicolumn{1}{c}{ Prilaku } & Nilai rata-rata & Ranah taksonomi bloom \\
\hline Pengetahuan & $77,2 \%$ & Mensintesa \\
Sikap & $76 \%$ & Karakteristik \\
Keterampilan & $75,7 \%$ & Artikulasi \\
\hline
\end{tabular}

Sumber: Data hasil penelitian (2018)

Perilaku peternak pada indikator pengetahuan berada pada tahap sintesis artinya responden sudah dapat mengemukakan ide-ide dalam kegiatan penyuluhan pembuatan nugget susu kepada orang lain. Indikator sikap berada pada tahap karakteristik artinya dapat meyakini mengenai pentingnya penganekaragaman produk melalui pemanfaatan susu kualitas rendah menjadi nugget susu yang nantinya akan dapat meningktakan nilai tambah atau pendapatan peternak sedangkan untuk indikator keterampilan berada pada tahap artikulasi artinya responden sudah terbiasa dengan langkah kerja pembuatan nugget yang telah diajarkan sebelumnya pada saat kegiatan penyuluhan.

\section{Hubungan Karakteristik responden dengan perilaku peternak}

Hasil penelitian tentang hubungan karakteristik peternak dengan perilaku dapat dilihat pada table 2 berikut ini:

Tabel 2. Hubungan Karakteristik

\begin{tabular}{llcccc}
\hline \multirow{2}{*}{ No } & $\begin{array}{c}\text { Karakteristik } \\
\text { Responden }\end{array}$ & \multicolumn{3}{c}{ Uji korelasi } \\
\cline { 3 - 6 } & $\begin{array}{c}\text { Pearson } \\
\text { Correlation }\end{array}$ & Sig. & Keterangan & F change \\
\hline 1 & Umur & $-0,094$ & 0,596 & $\begin{array}{c}\text { Tidak } \\
\text { signifikan }\end{array}$ & \multirow{2}{*}{0,000} \\
2 & Pendidikan & 0,716 & 0,000 & $\begin{array}{c}\text { Signifikan } \\
\text { Signifikan }\end{array}$ & \\
3 & Jumlah Ternak & 0,611 & 0,000 & &
\end{tabular}

Signifikan $=$ nilai sig. $<0,005$

Sumber: Data Hasil Penelitian (2018) 
Hasil uji korelasi berganda menunjukkan bahwa terdapat hubungan karakteristik responden terhadap perubahan perilaku dalam kegiatan penyuluhan tentang pembuatan nugget susu dan apabila diuji per variabel maka variabel yang berhubungan hanya pendidikan dan jumlah kepemilikan ternak.

Pendidikan peternak menunjukkan hubungan searah (positif) dengan prilaku peternak. Jika dikaategorikan berdasarkan interpretasi koefisien korelasi menunjukkan tingkat hubungan kuat yaitu 0,716 karena berada pada tahap rentan 0,61 - 0,80. Sedangkan signifikansi yang didapat adalah $0,00<0,05$ yang artinya adanya hubungan secara nyata antara pendidikan dan prilaku peternak. Sehingga semakin tinggi pendidikan seseorang akan sangat berpengaruhterhadap perubahan prilaku. Hal ini sesuai dengan pendapat Mubyarto di dalam Alim dan Nurlina (2007) bahwa tingkat pendidikan peternak akan mempengaruhi pola berpikir, kemampuan belajar, dan taraf intelektual.

Jumlah kepemilikan ternak menunjukkan hubungansearah (positif) dengan prilaku peternak. Jika dikaategorikan berdasarkan interpretasi koefisien korelasi menunjukkan tingkat hubungan kuat yaitu 0,611 karena berada pada tahap rentan $0,61-0,80$. Sedangkan signifikansi yang didapat adalah $0,00<$ 0,05 yang artinya adanya hubungan secara nyata antara pendidikan dan prilaku peternak. Sehingga semakin banyak jumlah ternak yang dimiliki maka perubahan prilaku terhadap kegiatan penyuluhan pembuatan nugget susu akan semakin baik. Hal ini sesuai dengan pendapat Amir (2017) bahwa jumlah ternak dapat dikatakan sebagai skala usaha dan dalam hal ini berhubungan dengan penggunaan sumber-sumber informasi. Pada dasarnya pemilik ternak banyak maupun pemilik ternak sedikit mempunyai tujuan yang sama dalam mengelola usahanya yaitu mendapatkan keuntungan untuk memenuhi kebutuhan sehari-hari sehingga peternak yang serius terhadap pekerjaannya akan mengalami perubahan prilaku

\section{KESIMPULAN}

Perilaku peternak dalam kegiatan penyuluhan pembuatan nugget susu di KWT Pandermania Desa Oro-oro Ombo menunjukkan bahwa rata-rata tingkat pengetahuan peternak adalah $77,2 \%$ berada pada tingkat sintes, pada tingkat sikap yaitu sebesar $76 \%$ berada pada tingkat mengelola sedangkan pada tingkat keterampilan 75,7 $\%$ responden berada pada tingkat artikualsi. Sedangkan hasil uji korelasi berganda menunjukkan bahwa terdapat hubungan karakteristik responden terhadap perubahan prilaku dalam kegiatan penyuluhan tentang pembuatan nugget susu dan apabila diuji per variabel maka variabel yang berhubungan hanya pendidikan dan jumlah kepemilikan ternak.

\section{UCAPAN TERIMAKASIH}

Termakasih kepada semua pihak yang telah membantu dalam penelitian ini, khususnya program studi penyuluhan peternakan STPP Malang.

\section{DAFTAR PUSTAKA}

Alim, S dan Nurlina, L. 2007. Hubungan antara Karakteristik dengan Presepsi Peternak Sapi Potong terhadap Inseminasi Buatan. Jurnal Ilmu Ternak. Universitas Padjadjaran. Vol. 7 No. 2.

Amir, S. 2017. Potensi Pengembangan Usaha Ternak Sapi Potong di Desa Balassuka Kecamatan Tombolo Pao Kabupaten Gowa. Skripsi. Program Sarjana. Fakultas Sains dan Teknologi. Universitas Islam negeri Alauddin. Makassar 
Mardikanto, T. 2009. Sistem Penyuluhan Pertanian. Surakarta : UPT Penerbitan dan Pencetakan UNS (UNS Press).

Mulyawati, dkk. 2016. Pengaruh Umur, pendidikan, pengalaman dan jumlahternak peternak kambing terhadap perilaku sapta usaha beternak kambing di Desa Wonosari Kecamatan Patebon. Fakultas Peternakan dan Pertanian. VOL 34 No 1 Universitas Diponegoro. Semarang.

Murwanto, A.G. 2008. Karakteristik Peternak dan Tingkat Masukan Teknologi Peternakan Sapi Potong di Lembah Prafi Kabupaten Monokwari. Jurnal Ilmu Peternakan.

Romadi, U. Hamyana. 2016. Persepsi Petani Terhadap Penggunaan Media Audio Visual Dalam Penyuluhan Pertanian di Kecamatan Junrejo Kota Batu. Jurnal Penyuluhan Pertanian Vol. 11 No.1 Mei 2016, hal 37-49.
Sugiyono. 2016. Metode Penelitian Kombinasi (Mixed Methods). Alfabeta: Bandung.

Warnaen, A., Nurlaili dan A.V. Sukmarini. 2017. Metode Komunikasi Penyuluhan Pertanian Melalui Radio Komunitas. Jurnal Ilmu Komunikasi Vol.8 No. 1 (2017). Universitas fajar Makassar. Download at: https://ejournal.unri.ac.id/index.php/J KMS/article/view/4231/4067

2016. Proses Adopsi Inovasi pada Petani di Kecamatan Polombangkeng Utara Kabupaten Takalar. STPP Medan.

Wibowo, S.A., dan Haryadi, F.T. 2006. Faktor Karakteristik Peternak yang mempengaruhi Sikap terhadap Program Kredit Sapi Potong di Kelompok Peternak Andiniharjo Kabupaten Sleman Yogyakarta. VOL 29 No. 3. Universitas gajah Mada. Yogyakarta 